\title{
The Effect of Drying Methods and Slice Thickness on Physicochemical Properties of Dry Gelugur Slice (Garcinia Atroviridis)
}

\author{
Mimi Nurmiah', Terip Karo-karo ${ }^{2}$, Elisa Julianti ${ }^{3}$, Vivi Andriani Ginting ${ }^{4}$ \\ \{miminurminah@usu.ac.id ${ }^{1}$, teripkaro@yahoo.co.id ${ }^{2}$, elizayulianti@yahoo.com ${ }^{3}$,gtgvivi@yahoo.com ${ }^{4}$ \} \\ 1,2,3,4 Department of Food Science and Technology, Faculty of Agriculture, \\ University of North Sumatera, Medan, Indonesia
}

\begin{abstract}
Garcinia Artroviridis (local name "asam gelugur") have been used in Indonesia for food like seasoning and tea. Another local foods that used asam gelugur were 'asam padeh and manisan asam gelugur. The farmers in Indonesia always dry the slice of asam gelugur fruits under the sun. The papers deals about using drying methods and slice thickness for asam gelugur slices on characteristic of physicochemical on dry gelugur slice. The drying methods that used for this research were using oven and the sun. The slice thickness consist three level: $3 \mathrm{~mm}, 5 \mathrm{~mm}$ and $7 \mathrm{~mm}$. The $3 \mathrm{~mm}$ slice thickness and oven method produced the best of dry gelugur slice..
\end{abstract}

Keywords: drying, slice thickness, physicochemical, gelugur, Garcinia atroviridis

\section{Introduction}

Garcinia atroviridis have been used for seasoning like asam padeh, manisan asam and gulai pindang in Indonesia. The kind of strain of garcinia fruits that generally found in Indonesia is Garcinia atroviridis, Garcinia combogia is common strain that we can find in Southern India [1]. In Indonesia, drying of Garcinia atroviridis traditionally using sun. There were many researchers had investigated about the principal acid of Garcinia atroviridis and Garcinia cambogia (-)-hydroxycitric (HCA) [2-3]. Other reports shown Garcinia atroviridis had strong antimicrobial and antioxidant antitumour-promoting activities [4]. This research deals about effect of drying methods and slice thickness on physicochemical properties of dry gelugur slice (Garcinia atroviridis).

\section{Method}

The research was conducted at Analisa Kimia Bahan Pangan Laboratory, University of North Sumatera. The Garcinia atroviridis were purchased from farmer at Sembahe, Deli Serdang, Indonesia. Fresh garcinia atroviridis were cut into flat of slabs consist 3, 5 and 7 $\mathrm{mm}$ in thickness. The slab were dried with 2 methods, consist dried under the sun and oven dried using cabinet drier at themperature $60^{\circ} \mathrm{C}$. After drying, the dry slice of Garcinia fuits were analyzed. Analysis consist of moisture content analysis by using oven method [5], ash content analysis using dry ashing method [5], total soluble solid [6], and vitamin $\mathrm{C}$ content [7]. Data analysis using randomized design were analyzed using SPSS version 22 for windows. Difference among the ranges of the properties were determinate using the method of Least Significant Differences (LSD) tests at 95\% confidence level $(\mathrm{P}<0.01)$. De Garmo was used in determining the best treatment method. 


\section{Results and Discussion}

\subsection{Effect of the Slice Thickness on Physicochemical Properties of Dry Gelugur Slice}

Figur 1 showed that the slice thickness of dry gelugur slice increased, the moisture increased too. When the slice thickness of dry gelugur slice increase, the moisture content will increase too. When we cut gelugur into slice that expand the surface of material, wide surface can be direct contact with the heating medium so that water diffuses more easily [8]. The thinner the dried material the faster the material dries.

Figur 2 showed that the slice thickness of dry gelugur slice had a very significant on ash content of dry gelugur slice. When the slice thickness of dry gelugur slice increase, the ash content will decrease, the higher of the slice thickness, the water need more time to evaporate and the temperature higher. The higher of moisture content, the lower ash content [9].

Figur 3 showed that the slice thickness of dry gelugur slice had a very significan effect on total soluble solid of dry gelugur slice. The lower of slice thickness the total soluble solid will increase. The lower of slice thickness so the water can evaporate easily. The increasing of ${ }^{\mathrm{O} B r i x}$ was caused of evaporating water from material [10].

Figure 4 showed that the slice thickness of dry gelugur slice had a very significant on vitamin $\mathrm{C}$ content of dry gelugur slice. The bigger of the slice thickness the lower vitamin $\mathrm{C}$ content. The bigger of slice thickness need more time to evaporate the water from material, meanwhile vitamin $\mathrm{C}$ can broke when the material were heated. The longer of the time for heating, the more vitamin $\mathrm{C}$ broke. Duration time of drying can make the lower vitamin $\mathrm{C}$ content [11].

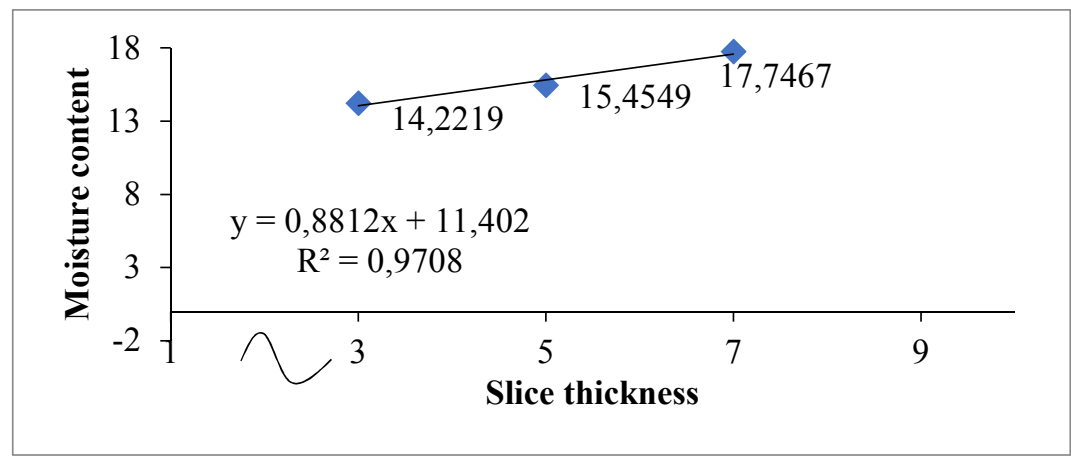

Fig 1. Effect of slice thickness on moisture content of dry gelugur slice 


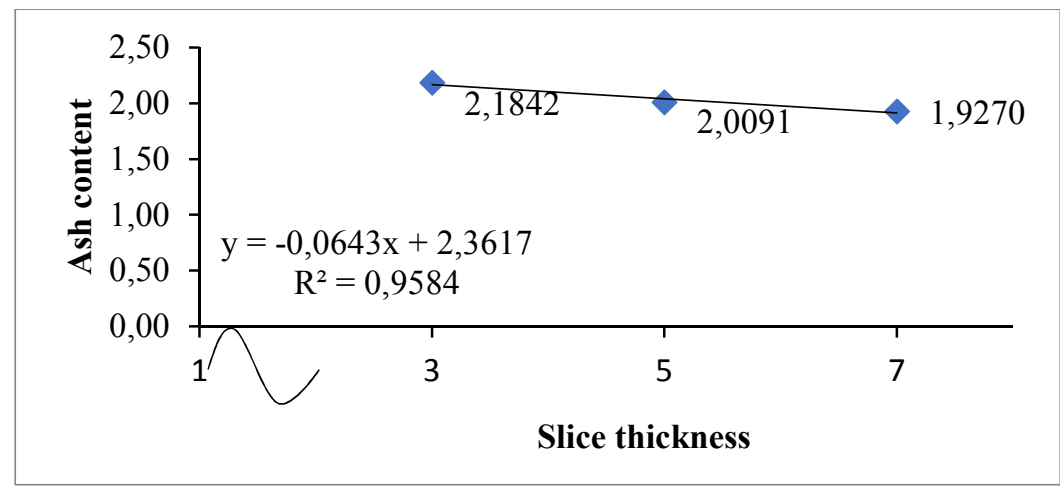

Fig 2. Effect of slice thickness on ash content of dry gelugur slice

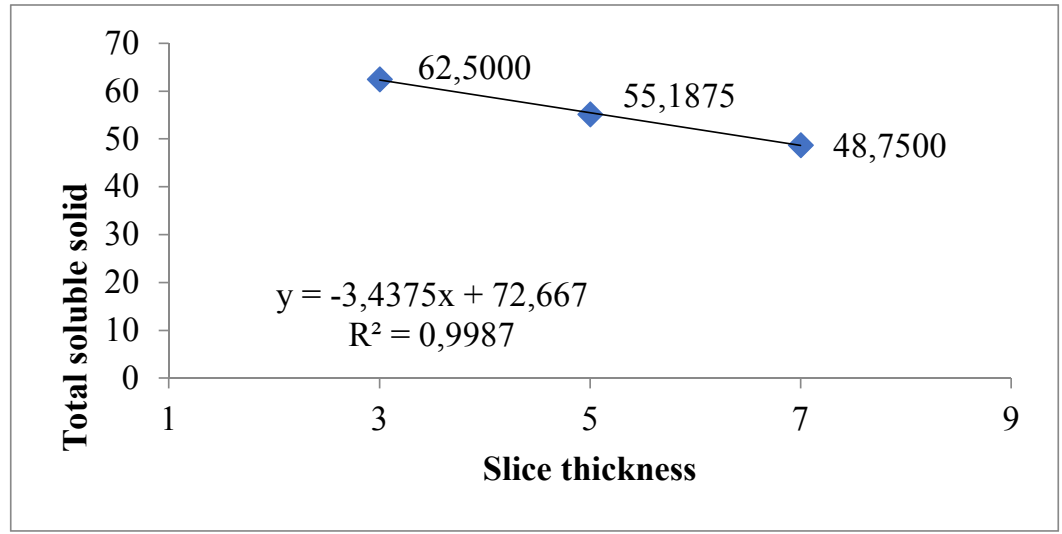

Fig 3. Effect of slice thickness on total soluble solid of gelugur slice

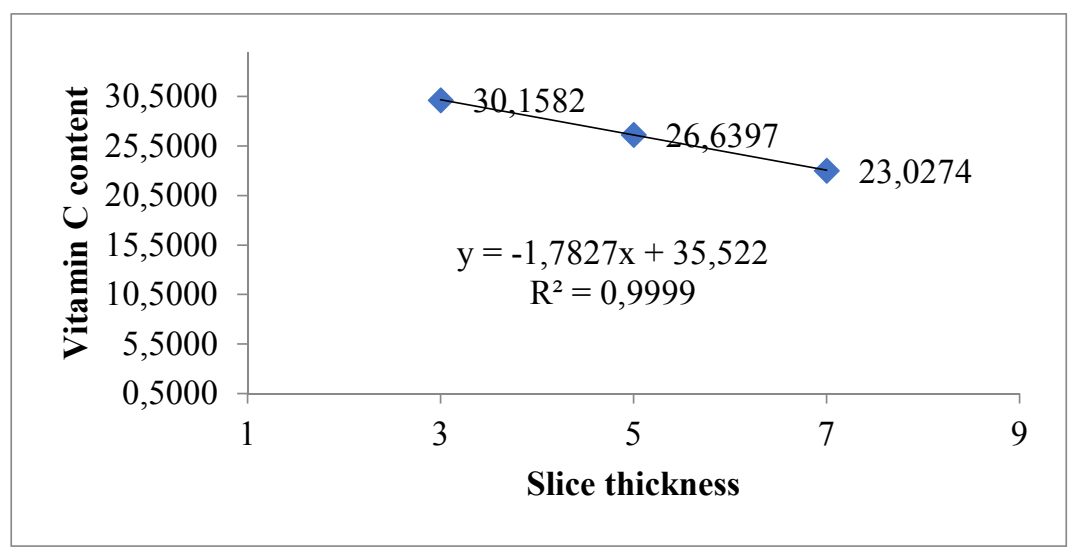

Fig 4. Effect of slice thickness on vitamin $\mathrm{C}$ content of gelugur slice 


\subsection{Effect of Drying Method on Physicochemical Properties of Dry Gelugur Slice}

Figur 5 showed drying method using sun (P2) had the highest value on moisture content of dry gelugur slice. Moisture content on oven drying (P1) are lower than sun drying (P2). The temperature were used in oven drying was high and the heat is spread evenly and the less time needed to dry the water [12].

Figur 6 showed that the drying method using sun had the lower value than using oven on ash content of dry gelugur slice. The highest value of ash content was oven drying method. Drying using oven method had stabil and high temperature, and the heat is spread evenly. Ash content depend on kind of material, ash method, time and temperature that used on drying method. The higher of drying temperature, the percentage of ash content will increase that caused water that evaporated from material bigger [13].

Figur 7 showed that the drying method using sun had the lower value than using oven on vitamin $\mathrm{C}$ content of dry gelugur slice. Vitamin $\mathrm{C}$ content on oven method was the highest value on vitamin $C$. The heating on sun method showed that there was ultraviolate light. The decrease of vitamin $\mathrm{C}$ content was caused of temperature, salt, sugar, time of heating and enzyme [14].

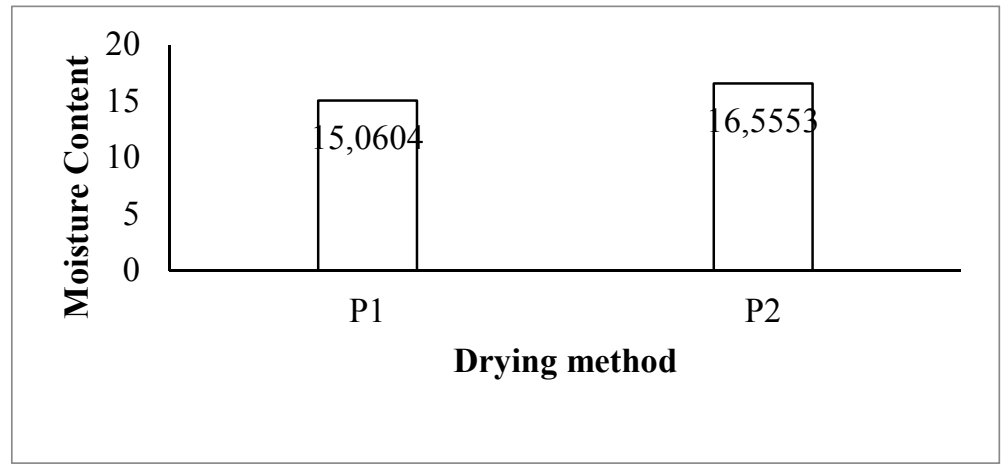

Fig 5. Effect of drying method on moisture content of dry gelugur slice

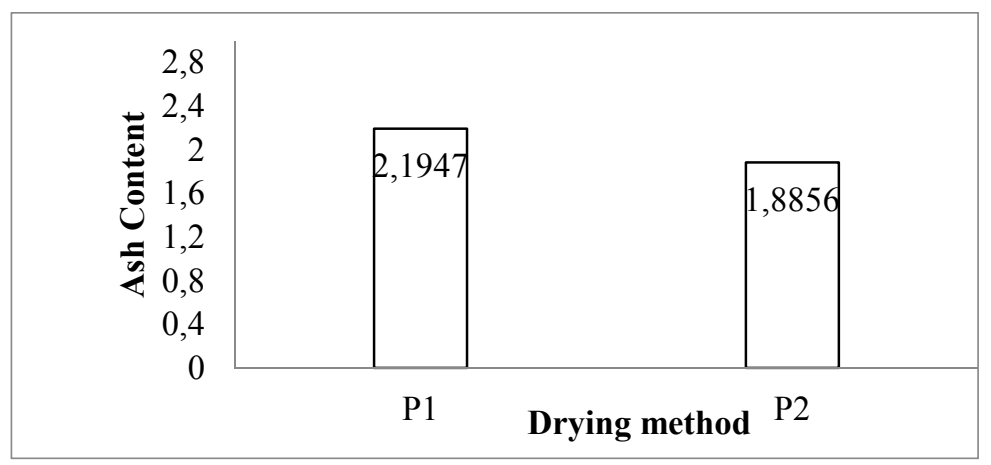

Fig 6. Effect of drying method on ash content of dry gelugur slice 


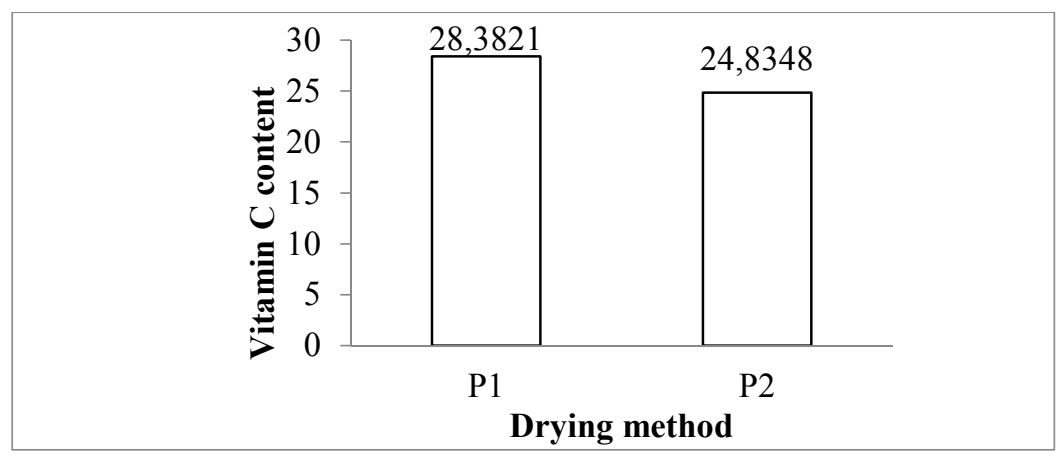

Fig 7. Effect of drying method on vitamin C content of dry gelugur slice

P1: oven drying

P2: sun drying

\section{Conclusion}

The $3 \mathrm{~mm}$ slice thickness and oven drying method produced the best of dry gelugur slice.

\section{References}

[1] Mackeen M M, Ali A M, El-Sharkawy S H, Salleh K. M., Lajis N. H. And Kawazu K, Hassan Z,Mohammed H, Mohidin A, Lim Y M And Mariam S. Antimicrobial, antioxidant, antitumor-promoting and cytotoxic activities of different plant part extract of Garcinia atroviridis Griff ex T. Anders. J. Ethnophamacol. 2000. 72, 395-402.

[2] K Hayamizu, Y Ishii, I Kaneko, M Shen, Y Okuhara, N Sigematsu, H Tomi, M Furuse, G Yashinoand H Shimasaki. Effect of Garcinia cambogia (Hydroxycitric acid) on viceral fat accumulation: A double-blind, randomized, placebo-controller trial. Curr. Ther. Res. 2003; 64, 551-67.

[3] Richard D Mattes and L Bormann. Effect of (-)-hydroxycitric acid on appetitive variables. Physiol. Behav. 2000; 71, 87-94.

[4] Mackeen, MM, Ali, AM Lajis, NH Kawazu, K Kikuzaki, H and Nakatani N. Antifungal Garcinia acid esters from the fruits of Garcinia atroviridis. Z Naturforsch, 2002. 57, 291295.

[5] AOAC. Official Methods of Analysis. Eleventh Edition. Association of official Analytical Chemists Inc. Washingto D.C. 1995.

[6] Sudarmadji S. B Haryono, and Suhardi. Analisa Bahan Makanan dan Pertanian (Analysis of food and agricultural materials). Liberty. Yogyakarta. 1997.

[7] Apriyanto A, D Fardiaz, NL Puspitasari, Serdanawati and S Budiyanto. Analisa Pangan (Analysis of food). PAU Pangan dan Gizi IPB (Centre between universities food and nutrition IPB). Bogor. 1989.

[8] Sugito., Hermanto, dan Arfah. Pengaruh ketebalan irisan dan suhu penggorengan hampa (vakum) terhadap karakteristik keripik labu kuning (Cucurbita moschata) (Effect of slice thickness and vacuum frying temperature on the characteristics of pumpkin chips). Jurnal Agroindustri (Agroindustry journal). 2013. 3(2): 83-97.

[9] Riansyah, A., A. Supriadi, dan R. Nopianti. Pengaruh perbedaan suhu dan waktu pengeringan terhadap karakteristik ikan asin sepat siam (Trichogaster pectoralis) dengan menggunakan oven (Effect of differences in temperature and drying time on the 
characteristics of salted siam using oven). Jurnal Fishtech (Fishtech Journal). 2013. 2(1): 53-68.

[10] Destriyani. L., Tamrin., dan M. Z. Kadir. Pengaruh umur simpan air tebu terhadap tingkat kemanisan tebu (Saccharum ofiicinarum) (Effect of Sugarcane water shelf life on sugarcane sweetness level). J. Teknik Pertanian Lampung (Agricultural Engineering Journal). 2014. 3(2):119-126.

[11] Marwati, Yuliani, Y. Andriyani, dan Mentari. Pengaruh suhu dan lama pengeringan terhadap sifat kimia dan organoleptik sale pisang kapas (Musa comiculata) (Effect of temperature and drying time on the chemical and organoleptic properties of cotton banana sale). Jurnal Kimia Mulawarman (Chemical Journal). 2017. 15(1): 22-26.

[12] Winangsih, E., P. Erna, dan S. Parman. Pengaruh Metode Pengeringan Terhadap Kualitas Simplisia Lempuyang Wangi (Zingiber aromaticum L.) (The effect of drying method on the quality of lempuyang wangi simplicia). Buletin Anatomi dan Fisiologi (Anatomy and physiology bulletin). 2013. 21(1): 19-25.

[13] Tambunan, Y. B., S. Ginting, dan L. M. Lubis. Pengaruh suhu dan lama pengeringan terhadap mutu bubuk bumbu sate padang (Effect of temperature and drying time on the quality of Padang satay spice powder). Jurnal Rekayasa Pangan dan Pertanian (Journal of Food and Agricultural Engineering). 2017. 5(2): 258-266.

[14] Simanjuntak, S. Nilai gizi dan organoleptik serta daya simpan minuman lidah buaya yang di blansing dengan waktu berbeda (Nutritional and organoleptic values and storing blanched aloe vera drinks at different times). Skripsi. Fakultas Pertanian. Universitas Riau. Pekanbaru. 2009. 